INGENIERÍA INDUSTRIAL

\title{
Modelacion lógica conceptual de un sistema tecnologico de trazabilidad turística
}

INDUSTRIAL ENGINEERING.

\section{Conceptual logic modeling of a Technological system of touristic traceability}

\author{
Gustavo A. Ramírez*, Ángela R. Chantre **, Carolina Delgado**§ \\ *Faculty of Electronic Engineering and Telecommunications. Telematics Engineering Department. \\ University of Cauca. Popayán. Colombia. \\ ** Faculty of Accounting Economic and Management Sciences. Department of Economics. \\ University of Cauca. Popayán. Colombia. \\ §carolinadelgado@unicauca.edu.co,gramirez@unicauca.edu.co,achantre@unicauca.edu.co
}

(Recibido: 08 junio de 2012 Aceptado: 13 septiembre de 2013)

\begin{abstract}
Resumen.
El presente artículo pretende describir y caracterizar el proceso de diseño y construcción de un Modelo Lógico Conceptual de ingeniería para hacer seguimiento y evaluación a la actividad turística de una región. Se detallan en forma clara los elementos funcionales y técnicos de un Sistema Tecnológico de Trazabilidad Turística que gracias a la incorporación de las tecnologías de diseño de software y herramientas web aporta a diversos grupos de interés reportes, indicadores e índices sobre perfil y comportamiento (trazas turísticas de recorridos y consumos, datos estadísticos de la actividad turística como la tipología del turista, sus visitas previas, intereses en otros destinos, motivos de viaje, género, posible gasto, rango de edad, transporte de llegada, nacionalidad y residencia). Dichos reportes, a través de sus métricas generan información, en vocabulario común a los involucrados, que facilita la toma de decisiones, mejoras y ventajas competitivas a nivel del sector y de las organizaciones que lo componen.
\end{abstract}

Palabras clave: gestión tecnológica, modelación lógica, sistema tecnológico de trazabilidad, turismo.

\begin{abstract}
.
This article aims to characterize and describe the designing and construction process of an engineering conceptual logic model to monitor and evaluate the touristic activities in a given region. It clearly outlines the functional and technical elements of a technological system of touristic traceability, that thanks to the incorporation of software design and web tools technologies,reports to severalstakeholders, indicators and indexes about profile and behavior variables (tourist traces of routes and consumptions, statistical data about the tourist activity and the typology of the tourists, their previous visits, their interests in other destinations, reasons for traveling, gender, possible expenditure, age range, transport on arrival, nationality and residence). These reports, through their metrics, generate information in a common vocabulary to the stakeholders, that facilitates decision-making processes, improvements and competitive advantages at sector level and its organizations.
\end{abstract}

Keywords: logic modeling, management of technology, technological system of traceability, tourism. 


\section{Introduction}

Tourism has been recognized as a determining factor in the economic growth of regions, due to its potential for employment generation and its contributions to the knowledge and dissemination of cultural values. Aguilera et al. (1996). In Colombia, the true commitment of the Government towards tourism could be seen specificallyat the year 2002, with the policy of democratic security, based on diagnostics resulting from the tourism competitiveness agreements.In despite of Colombia being a country of recognized natural and cultural biodiversityand having a tourist offer of seven products (Sun and beach, history and culture, agrotourism, ecotourism, sports and adventure, fairs and festivals and capital cities including shopping, health, congresses, conventions and incentives), Such \& Zapata (2009). It is clear that there are insufficient comparative advantages to attract and keep sustainably the global demand.

In response to this, at the national level, within the framework given by the current policy for tourism, there has been a general strategy formulated for the consolidation of a system of touristic information, leading to formulate Government policy and promote the use of information technologies and communication, which arises as a baseline for research works in the fields of electronic engineering in it's component of telematics, and industrial engineering in the component of management of technology, enabling to establish to what extent the implementation of a traceability system, specifically applied to the tourism sector, contributes to the structuring of a system of information that helps to the product design process, and positioning of the tourist destination and sector competitiveness.

\subsection{The technological system of touristic traceability: A sectorial strategy of competitiveness}

The concept of technological system, from the contributions of the historian of the american technology, Thomas Hughes, has been widely debated. Appealing to the author, we refer to it as the set of elements and variables related to the application of knowledge, which give context to the human and technical action generating comparative and/or competitive improvements or advantages. Puente (2009). Technological systems are built and adapted socially. Ibazeta (2004). The traceability system has been precisely conceptualized as technological because knowledge is the main asset within its resources, and according to the above concept, is the applied knowledge translated into tools, which allows an improvement or a competitive advantage provided by the system.

The traceability has been defined as the result of a measurement or the value of a standard where it may be related to specified references, usually national or international standards through a continuous chain of comparisons with specified uncertainties, ISO (2004). The concept of "tourist traceability" is used here, addressed in the literature by authors such as Xia (2007), Imfeld (2000) and Laube (2005), where they say that it is the set of actions and procedures to capture information about the tourists that visits a certain destination, in order to identify, register and learn about their behavior to design a touristic offer according to their needs, motivations and reasons in the touristic field.This concept is mainly approached from the marketing of tourist destinations discipline, referring to the promotion, advertising and communication techniques; focusing on the organization of the system of distribution and marketing of a destination, differentiating the actions and strategies that are used when it comes to organized tourism or an individual tourism. Ejarque (2003).

In the available state of the art about city marketing, this type of models contribute to the implementation of a strategy for the development of the city, that aims to satisfy, better than other competing cities, the needs of current and future users of all the services available in the city Kotler et al. (1994). Similarly, in the conceptual aspects, there is a change of paradigm in the traditional management of the city introducing the marketing in to the administration of the city, moving from 
the concept of citizen user to the concept of citizen client. De Elizagarate (2008).

\section{Methodology}

\subsection{The conceptual logic modeling as a tool for the construction of the of touristic traceability system}

The modeling of a system makes it possible for the stakeholders to get in touch with useful information about the improvement of the processes undertaken. It is a tool of management of technology represented in a visual method that demonstrates the relationships between resources, process, products or outputs, results or outcomes and impacts. According to Rush (2009), learning about the terms of the system is part of the process of logic modeling. The Kellogg Foundation,
W.K. Kellogg Foundation (2001) states that a logical model is a way to systematically and visually present and share the understanding of the relationships between the resources, the activities programmed (in a process) and the changes or results to be expected.

Below, and as shown in Figure 1 starts the deployment of the process of design and construction of the conceptual logical model for the touristic traceability system, which is based on the structural and functional modeling of its components or elements, actors, theory and interrelations:

Element 1. The Purpose in this work is:Responds to the question: $i$ To what extent the implementation of a system of touristic traceability contributes to structure a system of information for product design

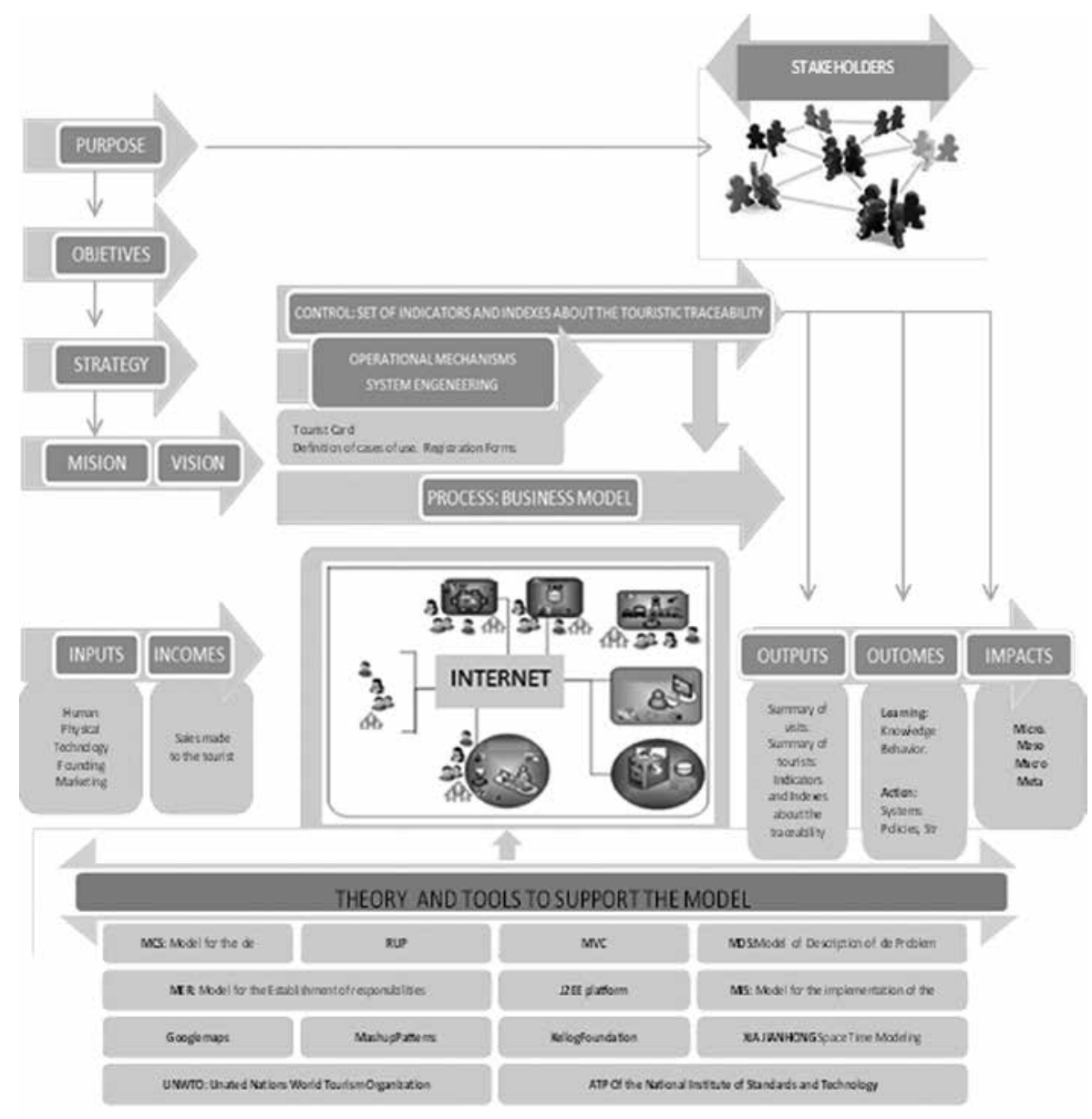

Figure 1. Touristic Traceability System Logic Model 
and helps the positioning of the destination?

Element 2. The main objectiveIs to design and implement a touristic traceability system as a base line to structure a regional system of touristic information.So the specific objectives are:To design and develop a virtual platform to capture information about the tourists based on their activities in a defined environment; and to select tools for the evaluation and follow-up of the touristic activity under the alternative of tourist traceability, and to assess the tourism activity in cycles of events.

Element 3. Thestrategy is theconsolidation of a traceability system applied to the tourism sector in cycles of events. (Moments of tourist activity).

Element 4. The system of touristic traceability is a technological tool that seeks to generate human, physical, environmental, marketing, financial and technological conditions to address the set of actions and procedures needed to capture information about the touriststhat visits a destination, in order to identify it and register it to provide certain profiles of information that can be useful to design a tourism offer according to their needs, motivations and reasons.

Element 5. To the year 2016, the system of touristic traceability will have become a model that might be extrapolated to other cities, regions and contexts.

Element 6. The System Engineering and operational mechanisms are: Tools and technical mechanisms adopting and adaptingall that it is proposed by the Kellogg Foundation in terms of the development of logical models. This tools also help modeling the scenarios that describe the behavior of tourists when theyvisit the city. The technical modeling helps to explain the operating system, as well as the behavior of tourists and the possible actions that the users of the tourist service points can make. The technical or engineering part can be seen in detail in the section presented in this article as the engineering of the project, in addition, the operational tools employed are as follows:

Tourist card: Card delivered to the tourist to get benefits such as discounts, promotions or gifts. This tool facilitates the trace because it captures data about consumption.

Definition of cases: It is a technical record of the moments of interaction with the tourist under major scenarios and scenarios of extension

Registration forms: They are used to capture information about the tourist profile: typology, nationality, gender, range of age, country and city of residence, etc.

Element 7. The model is structured to make deliveries of periodical reports to evaluate its performance in time, being this a process that involves the effort to compare actual performance with the standards and implement corrective actions, if necessary. This element has required the design of the following stages: Establishment of the standards of the system (quantity, quality, time and cost); Measurement of the performance of the system; Design and construction of indicators and indices, and finally, an Improvement Plan developed in a logical framework (problem, goal, strategy, activity, indicator, source of verification, people in charge, schedule and costs).

Element 8. For the purposes of this document theauthors show just a few examples: human resources: People involved in the system, (individuals or working groups as the technical team, and engineers, coordinators, students, practitioners, owners of the establishments, developers and providers of the tourism services (hotels, restaurants, museums, crafts, among others). Physical resources as those tangible means useful and ready for the operation of the system, financial resources, including those likely to be valued in monetary units as the contributions of members of the system or the co-executor of the project.Technological resources, as the media related to the application of knowledge to 
generate concrete improvements or advantages of a competitive nature as the software developed for the registration system, and the web page to register the tourist card. And finally the market resources, conceived as those used by the system to get in touch with the users, inform them and influence them, as the tourist card, POP material, registration forms, banners and posters of the associated establishments.

Element 9. Money that the system produces as a result of their own activity under market operation. In this particular case, the authors could mention the sales of services to tourists. However, it is appropriate to clarify that given the stage of implementation of the touristic traceability system, at this point there are not incomes or earnings resulting.

Element 10. The process carried out by the system has been modeled in the following scenarios:

Case 1: The tourist arrives to the airport or to the bus station in group or individually. The system provides the tourist card including a registration form and an information leaflet that contains suggested activities and sites to visit. At this point, the card is not enabled to make use of all the benefits. To enable it, the tourist must go to one of the "TAPs" defined. (From now on, the authors use the word "TAP" to denote the sentence Tourist Attention Point). These tourists, ask the enablement of the tourist card and deliver the registration form. If the hotel used by the tourist is not linked to the system, or if the tourist arrives at a particular house, then, the tourist card should be enabled in TAP located at the Chamber of Commerce in the city or at the Tourist Police Department.

Case 2: The tourist arrives at a hotel, then, receives the offer of the card by a receptionist who decides whether to deliver the card registration and brochure form or whether to make the registration of the tourist online and at the same time enabling the registration.

Case 3: The tourist arrives to a particular house: The tourist request information from the TAP at the Chamber of Commerce or the Tourist Police Department. In these places the registration is done online and they give the tourist the card and the information leaflet.

Element 11. The direct products support concretely the existence of the system. They have been modeled as reports and indicators and they are of two types: Summary of visits, which shows in detail the visits that have been registered in a particular TAP in a certain period of time. (by date from beginning to end; and by keywords). It also allows choosing the name of the TAP to view a special report on summary of visits.Summary of tourists, which corresponds to a statistical report showing the percentages of responses given by the tourists in the registration process. It also shows, in a table,the details about the registration of each tourist that was made in a particular TAP in a period of time.

The indicators that should be delivered by the system are: Indicators and indices about the tourist typology (individual, family, or group); About previous visits, About other destinations, reasons for travel, gender, possible expenditure, age range, transport on arrival: (air, terrestrial, public or private), previousknowledge about the destination, nationality and residence.

Element 12. These are the results that arise after the appearance of the outputs in the environment. It is modeled in two lines, the learning outcomes and the action outcomes:Learning Outcomes: Changes in knowledge. Variables that indicate what modifications occur thanks to the touristic traceability system, It shows the expected increases in knowledge about the tourism in the city. The tourist profile is an example of such a result. Similarly, there are changes in behavior, which demonstrate changes in the way that the sector works. The consolidation of events chosen to solve problems shown through the indicators in the outputs are an example of this. Finally there are changes in the skills, which are the new capabilities arising from the existence of the system. The ability to deliver information about the tourist in real time is an example of this. 
Outcomes or results at the action level: They are modeled in three types: changes in systems, (modifications occurring in different social systems related to tourism as a result of the touristic traceability system). The establishment of ad hoc committees or the emergence of organizations based on communal or associated work are an example of this. Similarly, there are changes in the policies, such as the creation or modification of Ordinances is a good example. Finally the model comes to the changes occurred in structures, they are variables that aim to demonstrate changes at organizational levels.

Element 13. The fundamental change (intentional or not) that occurs in organizations or systems that exchange flows with the system studied due to its intervention. Is the effect caused by the operation of the system of touristic traceability and occurs at different levels: at micro level, in which there is the integration of the individual agents to the interior of similar sectors, at meso level where joins the articulation of the traceability system with education and productive agents with the social and governance, at macro level in the structure that encompasses the scope of planningpolicies, strategies and regulatory frameworks that aim to construct a platform of management and sustainability of the knowledgebased competitiveness.In this type of structure, the Government creates the conditions required by each specific sector to play its role in the construction of competitiveness, and finally to the meta level incorporating the social capital of the country, in its capacity of integration and social strategy.

Element 14. The authors present here a selection of the main theorists in this area (models, methods and findings), provided by the ATP (Advanced Technology Program) of the National Institute of Standards and Technology, which have been synthesized for dissemination in the document A Toolkit for Evaluating Public R\&D Investment. Models, Methods and Findings from ATP's First Decade. US Department Of Commerce, Ruegg \& Feller (2003).
The main references that defined the development and implementation of the touristic traceability system, are the Kellogg Foundation, the UNWTO, World Tourism Organization, The Temporary Space Modeling provided by Jianhong XIA and the conceptual contributions of IMFELD Stephan and LAUBE Patrick.

Element 15. They are individuals or organizations with a direct or indirect interest, or, with an investment in the system. They guide the technical requirements of the system and the profile of the people to which the results or deliveries should issue. These are:

TAP: Users of a TAP that record the visit of tourists to their site and view statistics reports: these are mainly restaurants, cafeterias and food sites, museums, theatres and exhibitions, among others.

TAP with privileges: users of a TAP enabled to perform specialized actions, such as registration of tourists, activation and reallocation of the card, display of specialized reports, delivery forms for registration and registration of the visits that do not have web access: Chambers of Commerce, Governorate or district entity, police of tourism and hotels.

Manager: User that does not belong to any kind of TAP, but can perform specialized actions such as the allocation of permits to each type of TAP and thevisualization of specialized reports.

Technical team / engineering: Compound by a Coordinator, an engineer expert in tourism (acknowledged by Colciencias), a tourism development adviser, a specialist in tourism marketing, an engineer expert in web development, an electrical engineer expert in requirements of capture, lifting models and technical assistance in software engineering for the encryption of models and design of the card.

The system partners: Their mission covers the optimal facilitation of requirements to operate. 
Including investors such as the public University, the departmental Bureau of tourism, the Chamber of Commerce, the tourism police and the national service of learning SENA.

Tourist: The World Tourism Organization has defined the concept of tourist differentiating: international visitor tourist, domestic visitor tourist, tourist visitor that stays overnight and tourist visitor of the day.

\subsection{Design of a pilot test for the touristic traceability system}

Logic models, given its perfectible nature, conceived as "technical abstractions" of the observed reality, require a validation process, allowing adjustments to come closer to the ideal. As a result, an investigation was designed within the public University. The purpose was to ensure that the modeling made meets the expectations of the system in terms of its components and its operation, as well as identify and correct deficiencies that could cause deviations in the achievement of the objectives.
The pilot test was designed under the following considerations: it was born as an initiative in the Departmental Bureau of Tourism of the Cauca Department in the year 2010, given the lack of data and tourist information in the region. The pilot project, applied to the city of Popayan, began with a contribution of $\$ 18.288 .458$ provided by the University of Cauca and $\$ 35.000 .000$ placed by of the Governorship of Cauca. It was also made with the support of coordinating organizations like the Cauca Chamber of Commerce, Police Department of Tourism and the National Service of Learning SENA; all of them institutions designed as partners of the system given their mission. Their participation was effective to achieve a screenshot of the tourist information, follow the tourist activity in places such as museums, hotels, restaurants, crafts etc. In the pilot test, the touristsreceived the card, which was conceived to be presented at different establishments to enjoy sales and special prices. The goals for the pilot project were formulated taking into account the design and development

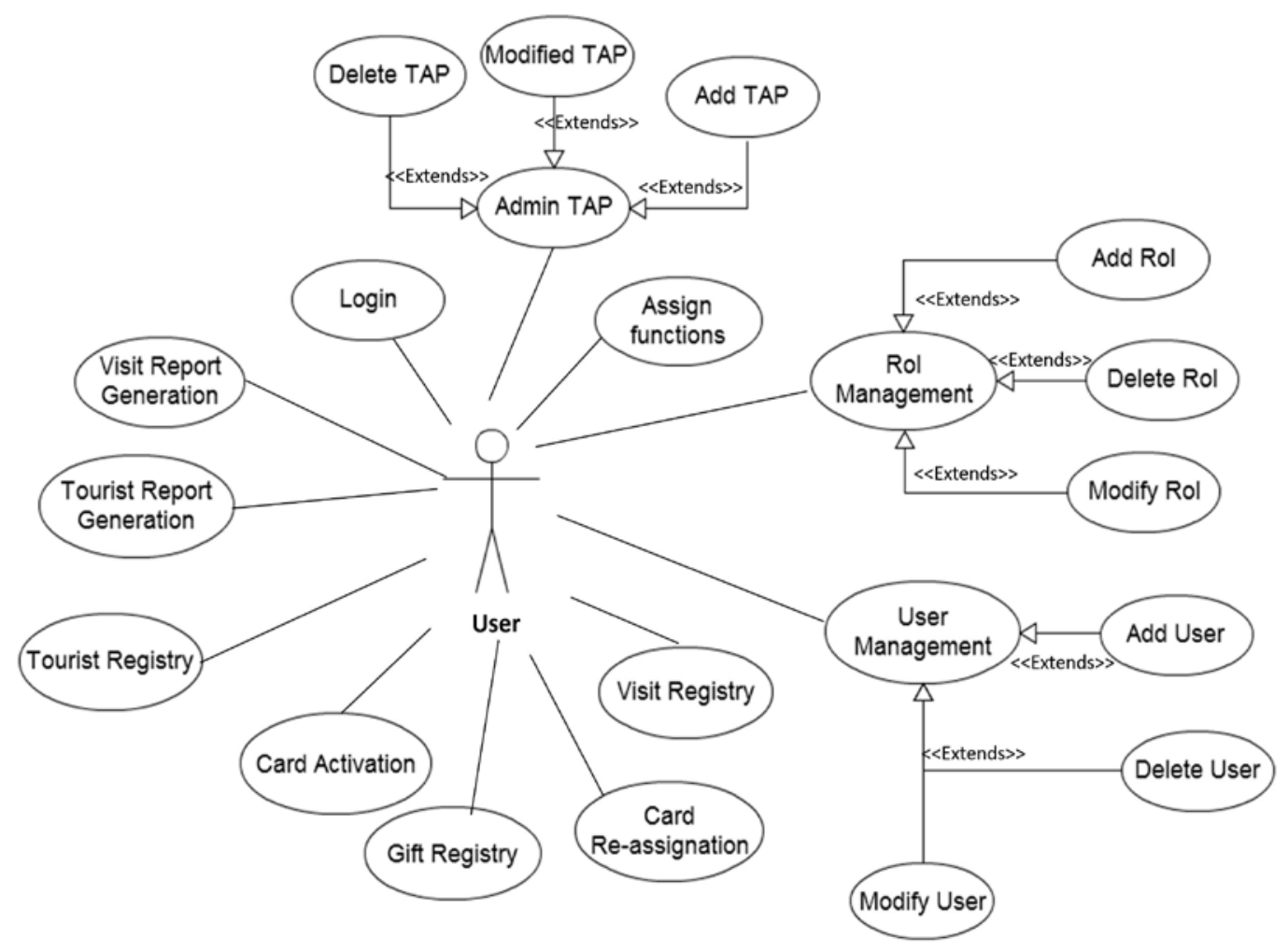

Figure 2. Cases of Use Diagram: TAP Manager 
of a virtual platform to capture the information of tourists based on their activities in a defined environment, implementing a test for evaluation and monitoring of tourism and the validation of the functional and structural component of the model.
MCS (model construction of solutions) Serrano (2005) which is a landmark in development of projects of RUP (rational unified process). Kruchten (2000), which generates three intermediate models that support the proposed model engineering: MER (model establishment of responsibilities), MDS

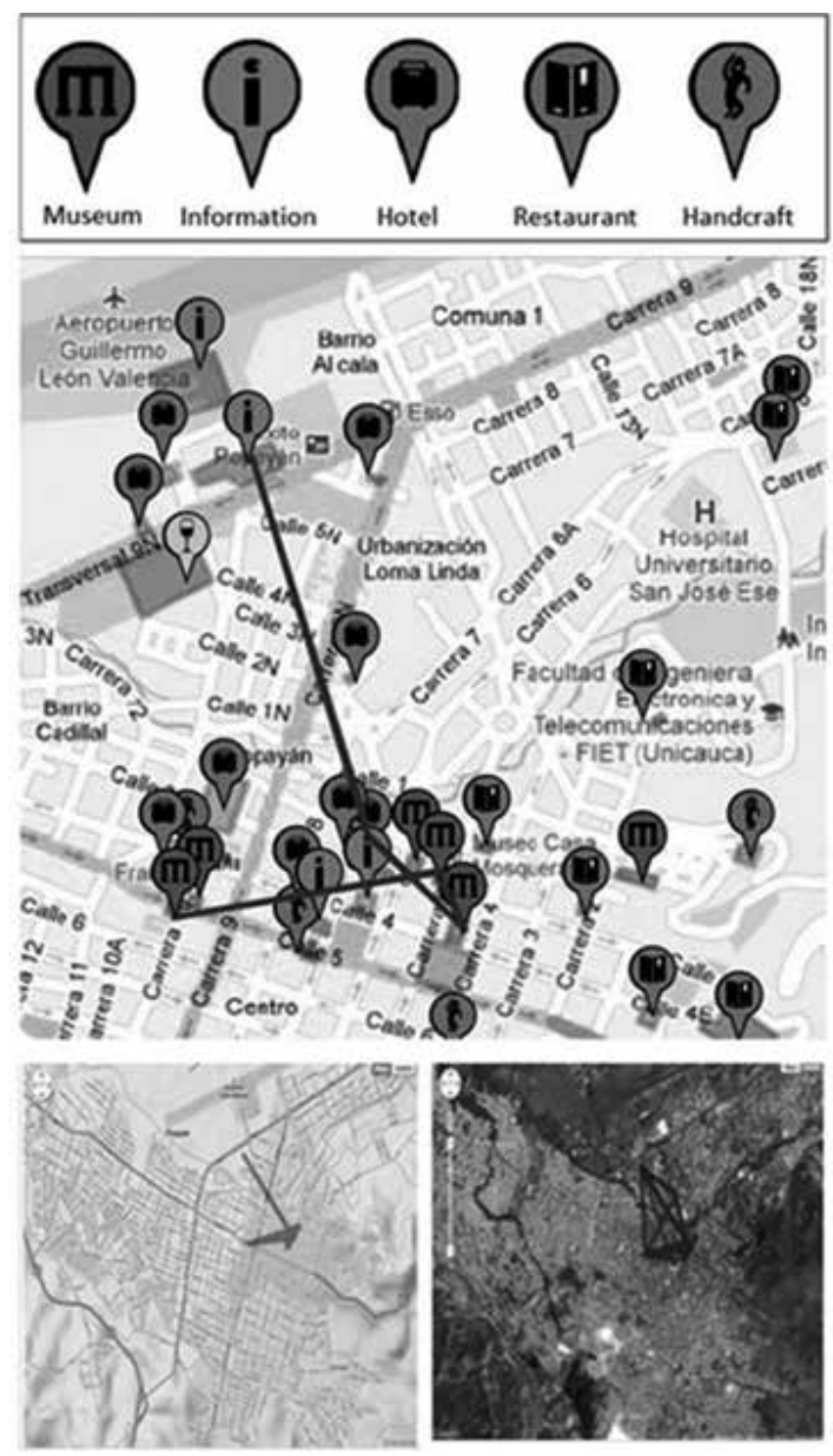

Figure 3. Maps about the tourist trace

\subsection{The engineering of the model}

The technological and engineering characteristics of the system are concentrated, in addition to the logical modeling as an element of technological management in the proposed methodology in the (model for description of the system) and MIS (model for implementation of the system).

From an architectural point of view, this is a MVC architecture (Message-based MVC Paradigm), Xiaohong (2004), in an environment of enterprise 
web application based on the J2EE platform. Kassem (2000). It is relevant the functional features made for the TAPs, shown in high level through the use of case diagrams (see figure 2), and a business model, to model the information of tourists based on the application of the logic model proposed. The Support architecture for the visualization of the trace is based on a system of Mashups Patterns, Cheng-Jung et al. (2009) and Zhenzhen et al. (2011), under Google Maps referenced in Curran (2007), Dunnavant(2010) and Svennerberg (2010) on the map of the city of Popayán. It was possible to identify the places of greater assistance , and the types of tourists who visited the city of Popayán during the Holy Week, (the analysis of the information facilitated its categorization). Figure 3 shows the maps generated dynamically about the movement of tourists information.

\section{Results and discussion}

Figure number 1 shows the methodological elements and tools used by the project; it displays graphically the way in which the logic modeling is used as a tool for the construction of a touristic traceability system.

The methodology and tools chosen for this purpose were successful; it was possible to track the tourist activity of a given city, getting the first statistics at the Holly Week of 2011. Below are the results obtained in the registration of tourists by the different TAPs:

General statistics obtained: $79.7 \%$ of the tourists move to Popayán in car $(36.7 \%$ and $43 \%$ by public transportation and using their own vehicle), corresponding to airplane a share of $17.8 \%$. This is consistent with the poor touristic connectivity structure that has the Department of Cauca. $63 \%$ of tourists have clearly identified the city of Popayán as a destination during the season, while $35 \%$ consider other destinations, which opens up possibilities for other alternatives of tourism development.

Tourist traces: First, the project created a generic model for the touristic trace, later, the system provided as results specialized traces like the external tourism trace, showing the route of this type of tourists and the concentration of tours by small areas of the city where the study was applied, and the trace of national tourism, which traces the route of the national tourists (see Figure 3). These traces demonstrate a high concentration of the national tourism in the historic area, differing from the trace of foreign tourists.

\section{Indicators and indexes from the traceability system: some of these indicators are:}

Indicators about the tourism type: Individual: 346 or $27.7 \%$. Family: 755 , or $60.5 \%$. Group: 138 , or $11.1 \%$

Indicators about previous visits: 639 , or $51.2 \%$. Without previous visits: 607 , or $48.7 \%$.

Indicators about other destinations, or touristic places: 470 or the $37.7 \%$. Without: 776 , or $62.2 \%$.

Indicators about the reason to travel: Leisure Tourism: 925 or $74.2 \%$. Work/business: 45 , or $3.6 \%$. Events: 82 or $6.6 \%$. Health: 1 or $0.1 \%$. Family travel: 164 or $13.2 \%$. Another reason: 12 or $1 \%$.

Indicators about the tourist gender: Male: 573, or $46 \%$. Female: 660 , or $52.9 \%$.

Indicators about possible expenditure (given and calculated in Colombian pesos): Between 0 and $\$ 500.000$ correspond to 617 , or $49.5 \%$. Between $\$ 500,000$ and 1 million: 250 equivalent to $20 \%$. Between 1 million and 3 million: 108, equivalent to $8.7 \%$. 3 Millionor more correspond to 17 , or $1.4 \%$

Indicators about the age ranges: Less than 18 : 62, or $5 \%$. Between 18 and 30: 417, or $33.4 \%$. Between 30 and 50: equivalent to the $40.1 \%$. More than 50: 225, equivalent to $18 \%$.

Indicators about transportation for arrival: Air: 222, equivalent to the $17.8 \%$. Terrestrial (public): 540 , equivalent to the $43.3 \%$. Terrestrial (private): 458 , value representing the $36.7 \%$. 
Indicators about the Prior knowledge of the destination: Internet: 37. Tour operator: 7, or $0.6 \%$. Travel agency: 6 , or $0.5 \%$. Reference: 301 , or $24.1 \%$. Advertising: 70 , or $5.6 \%$. Prior knowledge: 810 , or $65 \%$.

Indicators about nationality: Colombia: 1137, value representing the $91.2 \%$. United States: 21 , equivalent to the $1.7 \%$. The system reported other indicators with percentages lower than $1 \%$ for countries such as: United Kingdom, Russia, Germany, Italy, Netherlands and France among others.

Indicators and Indexes about the tourist residence: Colombia: 1126 , or $90.3 \%$. United States: 19 , or $1.5 \%$, The system reported other indicators with percentages lower than $1 \%$ for residences in countries like United Kingdom, Russia, Germany, Netherlands and France among others.

Indicators and Indexes by TAP: The engineering design of the model, in order to generate a valuable contribution to the management of the related organizations, whether they were hotels, museums, crafts or another business, was prepared to generate indicators using the reports of each TAP.

Using the principles underpinning the logical concept of a technological system of touristic traceability, the present study showed that it coincides with the main theorists referents available on the state of the art, citing mainly the approaches given by Jianhong Xia, Stephan Imfeld and Patrick Laube, authors that in their workcharacterize the concept of traceability applied to the specific field of tourism.

Apart from presenting a relative consensus between the design of the research and theory of these authors, it is useful to highlight the characteristics of the technological innovation of the system, which is presented as the first initiative in the country for tracking technical traceability to the tourist activity in a particular territory. These elements, in its synergy, had not been previously used. Regarding the characterization and reporting of outcomes and impacts, the perception of the stakeholders is very positive. So far there have been collected and registered indications of a high acceptance of the system among the participating organizations, which is also seen at the opinions given by them at the events of socialization of the results.

The design of this type of model allowed stakeholders having fullknowledge about the tourism of the city and provide, therefore, a reliable tool for the description of the tourist market in a given event. This is a representative significance since it becomes an input for decision-making involving market segmentation, especially in cases in which it is important to differentiate the national from the international tourism.

However, it is required the construction of metrics that allow quantifiable and verifiable measurements. This fact outlines future and additional research to make measurements about outcomes and impacts, also assessments to achieve value judgments about the behavior of the variables and other valuations to assign economic value to the behavior analyzed.

\section{Conclusions}

The concept of traceability could be successfully linked to the field of tourism through the logic modeling of a tourist traceability system with the technological support of a software development tool.

Given the main objective of designing and implementing a touristic traceability system, and also given the specific objectives ofdesigning and developing a virtual platform, selecting tools for the evaluation and assessing the tourism activity the project reported specific traces, statistics and indicators that satisfied and fulfill the requirement.

Through the implementation of the model of touristic traceability system, it was possible to make the layout, or sketch, to identify the routes and consumption of the tourists on a map of the studied territory and report metrics and socio- 
demographic statistics for the construction of profiles during a season of high demand for services as it was the holly week. These multiple traces allowedto conclude important aspects regarding the route of the tourists in a territory and in the same way to differentiate behavior profiles by type of tourist.

The tourist traceability system contributed to the stakeholder'sspecific reports about the tourist activities in the region in data as the typology of the tourists, their previous visits, their interests in other destinations, reasons for travel, gender, possible expenditure, age range, transport of arrival, and nationality and residence. Thanks to this reports it was possible to conclude that $74 \%$ of the tourists that visited the city are part of the leisure or recreation tourism, $13 \%$ of them came for family interests and $7 \%$ attracted to the different commercial events that were offered parallel to the main event of Easter. This confirmed that the holly week is the main event during the year.Popayán presents mainly a national tourism (91\%) with an international component ( $9 \%$ ) very diverse: ( 24 countries all over the world), whose greater influx comes from the United States, Germany, France, Mexico, Ecuador and Spain, which suggests a potential market with high spending power.

Given the lack of reliable statistics, this model became an interested tool to establish the tourism demand based on budget spending data. There is information provided in this field, for example, it tells that the $50 \%$ of the tourists expected a budget spending of $\$ 500.000$ Colombian pesos, 5,000. (approximately US\$288, and 190 euros); $20 \%$ has planned twice this amount, while $8 \%$ expected a spending limit of three million Colombian pesos (US\$ 1,667, 1,139 euros).

After crossing this information with the percentage of tourists according to nationality, the project allowed to infer that the range of tourist expenditure of the Colombian ranges goes between US\$ 288 and US\$ 576 while foreign tourist expenditure goes to approximately US\$ $1,667$.
In regards to the impact of advertising and the Internet as mediation is virtually non-existent or ineffective as a mechanism for the promotion of the destination, argument that confirms the necessity of structuring a true system of tourist information to broaden the scope for destination marketing.

Considering that most of the tourists belong to a family type $(60 \%)$, thatthe $27.7 \%$ are individual tourists and $11 \%$ are groups, it opens another good possibility for the above-mentioned mainland, especially if we consider that the vast majority of tourists present an age range that makes them suitable to undertake complementary activities such as a potential segment very important for this type of offer. ( $70.5 \%$ of the tourists is in a range of age between 18 and 50 years $-33.4 \%$ and $43.1 \%$, respectively).

The opportunity to conduct a pilot study at the level of a given city with the linking of multiple authorsshows the relevance of this type of models to generate information to facilitate improvements and competitive advantage at the level of the tourism sector and its organizations.

The modeling of the system allowed to create a common vocabulary within the stakeholders of the tourism at a regional level and has become a standard to rank models for the generation of information and statistics in touristic regions. The model, its operational mechanisms and the metrics considered are not unchangeable. Further research and more refined calculations will validate it.

There is notauniversal and unique answer for measurement, evaluation and assessment of the tourist activity. The work carried out so far, is the first approximation to this effort.

\section{Acknowledgements}

The authors want to make a special recognition to the support provided by the University of Cauca, to the Vice Presidency For Research Affairs; to 
the Faculty of Electronic and Telecommunications Engineering (Department of telematics), to the Faculty of Accounting, Economic and Management Sciences, (Department of Economics), to the Tourism Program, its teachers and students, to the managers of the Telematics Engineering and Tourism and Regional Development research groups and their teams of researchers, to the governorship of Cauca, the Bureau of tourism of Cauca and the Commerce Cauca Chamber. All of them, through their important processes, provided relevant information for this article.

\section{References}

Aguilera, M., Bernal, C., \& Quintero, P. (1996). Turismo y desarrollo en el Caribe colombiano. Documentos de trabajo sobre economía regional 79, Banco de la República, Cartagena, Colombia.

Cheng-Jung, L., Shung-Ming, T., Chang-Chun, T., \& Yu-Chuan Ch. (2009). Toward a new paradigm: Mashup patterns in web 2.0.http:// dl.acm.org/citation.cfm?id=1718134

Curran, K. (2007). Geographical Mashups. IEEE Distributed Systems Online. http://dx.doi. org/10.1109/MDSO.2007.20

De Elizagarate, V. (2008). Marketing de Ciudades. Madrid: Pirámide.

Dunnavant, S. (2010). Create interactive web illustrations with google maps. In Proceedings of the 38th annual fall conference on SIGUCCS. http://doi.acm.org/10.1145/1878335.1878401

Ejarque, J. (2003). Destinos Turísticos de Éxito. Milán: Pirámide

Fundación W.K. Kellogg (2001). Guía de Desarrollo de Modelos Lógicos. Michigan: USA.

Ibazeta, R. (2004). El sentido de la creatividad en la educación tecnológica. http://weblog.mendoza. edu.ar/autores/archives/002653.html
Imfeld, S. (2000). Times, points and space, towards a better analysis of wild life data in GIS. Faculty of Science. University of Zurich, Zurich, Suiza.

ISO (International Organization for Standarization). (2012). International Vocabulary of Basic and General Terms in Metrology. http://www.bipm.org/ utils/common/documents/jcgm/JCGM 2002012. pdf

Kassem, N. (2000). Designing Enterprise Applications with the J2EE Platform. Sun Microsystems, 1nc.Red Lion, PA, U.S.A: Addison-Wesley Professional.

Kotler, P., Haider, D., \& Rein,I. (1994). Marketing Places. Mexico: The Free Press.

Kruchten, P. (2000). The Rational Unified Process: An Introduction, Second Edition. Boston: AddisonWesley Longman Publishing Co., Inc.

Laube, P. (2005). Analyzing Point Motion Spatio-Temporal Data Mining of Geospatial Lifelines. Doctoral Thesis, Mathematischnaturwissenschaftlichen Fakulat, Universit at Zurich, Zurich, Suiza.

Puente, J. (2009). Un estudio sobre las implicaciones sociales y cientificas de la técnica. El Sistema Tecnológico. http://web.educastur. princast.es/proyectos/grupotecne/cts/sistecl.htm

Ruegg, R., \& Feller, I. (2003). A Toolkit for Evaluating Public R\&D Investment Models, Methods, and Findings from ATP's First Decade: NIST GCR.

RUSH (Research Utilization Support and Help). (2009). Learn about the utilization logic models. http://www.researchutilization.org/logicmodel/ learn.html

Serrano, C. (2005). Modelo para la construcción de soluciones, modelo integral para el profesional en ingeniería. Popayán: Ed. Universidad del Cauca. 
Such, M., Zapata, S., Risso, W., Brida, J., \& Pereyra, J. (2009). Turismo y crecimiento económico: Un análisis empírico de Colombia. Estudios y perspectivas en turismo 18, 21-35. http://www.scielo.org.ar/scielo.php?script $=$ sci serial\&pid=1851-1732\&lng=es\&nrm=iso

Svennerberg, G (2010). Beginning Google Maps API 3. Berkely: Apress.

Xia, J. (2007). Modeling the spatial-temporal movement of tourists. School of mathematical and geospatial sciences. RMIT University. Melbourne: Australia.
Xiaohong, Q. (2004). Building Desktop Applications with Web Services in a Messagebased MVC Paradigm. In Proceedings of the IEEE International Conference on Web Services, San Diego, California, USA. http://dx.doi.org/10.1109/ ICWS.2004.31

Zhenzhen, Z., Sirsha, B., Liu, J., \& Crespi, N. (2011). Mashup services to daily activities: end-user perspective in designing a consumer mashups. In Proceedings of the 13th International Conference on Information Integration and Web-based Applications and Services, Ho Chi Minh City, Vietnam. http://doi. acm.org/10.1145/2095536.2095574 